\title{
Transferase Deficiency Galactosemia
}

National Cancer Institute

\section{Source}

National Cancer Institute. Transferase Deficiency Galactosemia. NCI Thesaurus. Code C81325.

A disorder characterized by the body's inability to metabolize galactose. This type of galactosemia is caused by germline mutations in the GALT gene which leads to the inhibition in the activity of the enzyme galactose-1-phosphate uridyl transferase. 